\title{
GLOBAL SATELLITE NAVIGATION SYSTEMS AT HIGH LATITUDES, VISIBILITY AND GEOMETRY
}

\begin{abstract}
Since few years the significance of the navigation at high latitudes $\left(60^{\circ}\right.$ and more), increases incessantly, e.g. northern passages between Atlantic and Pacific Waters. In these regions the user's position can be obtained mainly from global satellite navigation systems (SNS). Nowadays (September 2016) two systems, American GPS and Russian GLONASS, are fully operational, two next, Galileo in Europe and BeiDou in China, are under construction. As the error of user's position obtained from these systems depends on geometry factor DOP (Dilution Of Precision) among other things the knowledge of the number of satellites visible by this user above given masking elevation angle $\mathrm{H}_{\min }$ and the distributions of DOP coefficient values, GDOP in particular, is very important. The lowest and the greatest number of satellites visible in open area by the user at high latitudes for different $\mathrm{H}_{\text {min }}$, the percentage of satellites visible above angle $\mathrm{H}$, distributions of satellites azimuths and GDOP coefficient values for different $\mathrm{H}_{\min }$ for all these four SNSs at different user's latitudes (beginning from $60^{\circ}$ ) and other distributions are presented in the paper. All calculations were made for constellation of BeiDou 27 MEO satellites, Galileo 24 satellites, GLONASS 24 and GPS 31 satellites.
\end{abstract}

\section{Keywords:}

satellite navigation system, visibility of satellites, geometry of the system.

\section{INTRODUCTION}

Nowadays (September 2016) two global satellite navigation systems (SNS), American GPS and Russian GLONASS, are fully operational, two next, Galileo 
and BeiDou, are under construction in Europe and China, respectively. Additionally four satellite based augmentation systems (SBAS), EGNOS in Europe, WAAS in USA and Canada, MSAS in Japan and GAGAN in India are operational also, one next, SDMC in Russia is under construction [Januszewski, 2016], [www.gpsworld.com], [www.insidegnss.com].

Since few months the number of GPS satellites fully operational is 31 and this number was taken into account in the paper. In the case of GLONASS system the number of satellites on the orbits with different status is usually greater than nominal number 24 but the calculations were made just for this number [www.glonass-ianc.rsa.ru], [www.gps.gov].

The Galileo constellation design was originally planned based on a three-plane constellation with a minimum of nine operational satellites in each plane and three active spares, one per orbital plane; total number of satellites - 30 . Over the course of time the planned Galileo constellation changed and in 2014 these changes became evident. Currently the reference space segment has 24 operational satellites only with up to six operating spares - two in each plane. The eight satellites in each plane are equally spaced; locations of the spares will be determined [European GNSS, 2016], [www.gsc.europa.eu].

As the BeiDou constellation of 3 IGSO and 5 GEO satellites can be used in limited area, China and Asia-Pacific region, the constellation of 27 MEO satellites only will be taken into account. Currently there are 20 BeiDou satellites in orbit and healthy and one with status in commissioning and 9 Galileo operational satellites, 4 with status in commissioning and one partially unavailable. Full Operational Capability (FOC) of BeiDou and Galileo systems is planned in 2020 [Munich, 2016], [www.beidou.gov.cn].

That's why all calculations were made for constellation of 31 GPS satellites, 24 GLONASS, 24 Galileo and 27 BeiDou MEO satellites.

SBASs were not taken into account in this paper because of limited range of each system, the range of geostationary satellite, in particular and no sufficient number of terrestrial monitoring stations at high latitudes.

\section{NAVIGATION AT HIGH LATITUDES OF NORTHERN HEMISPHERE}

Since few years the significance of the navigation at high latitudes $\left(60^{\circ}\right.$ and more), increases incessantly, e.g. more and more frequent northern passages 
between Atlantic and Pacific Waters. The merchant vessels navigate in the Boris Vilkitsky strait $\left(78^{\circ} \mathrm{N}, 103^{\circ} \mathrm{E}\right)$ between the Taimyr Peninsula and Bolshevik Inland in the Severnaya Zemlya archipelago at the time. Since May 2016 the super-luxury cruise ships navigate from Vancouver and Anchorage to New York across Beaufort Sea, around the north end of Baffin Inland $\left(75^{\circ} \mathrm{N}\right)$. This route connecting Pacific Ocean and the Northern Atlantic Ocean through the Arctic Ocean is called the Northwest Passage [www.globalnews.ca].

The latitude of many ports or populated inlands in different countries is greater than $60^{\circ}$, e.g. Husavik (Island) $66^{\circ} \mathrm{N}$, Narvik (Norway) $68^{\circ} \mathrm{N}$, Nordvik (Russia) $74^{\circ} \mathrm{N}$, Spitsbergen (Norway) $80^{\circ} \mathrm{N}$.

In all these regions and ports the current position can be obtained mainly, and sometimes only, from global SNSs. That why we can put several questions:

1. How many satellites of each SNS is visible at high latitudes?

2. Which is geometry of each SNS at high latitudes?

3. Which SNS is the most useful in this region and why?

\section{GLOBAL SATELLITE NAVIGATION SYSTEMS CONSTELLATIONS}

The parameters of spatial segment, the number of MEO satellites and time interval of constellation repeatability of all four SNSs are presented in the table 1. Galileo orbit altitude and GLONASS orbit inclination are the highest, $23,222 \mathrm{~km}$ and $64.8^{\circ}$, respectively.

The geographical longitude of ascending node and argument of latitude of all satellites are presented in the Table 2 - BeiDou, Table 3 - Galileo and GLONASS, and Table 4 - GPS.

\section{Test methods}

All calculations based on reference ellipsoid WGS-84 were made on author's simulating program. The interval of the latitude of the observer between $60^{\circ}$ and $90^{\circ}$ was divided into 6 zones, each $5^{\circ}$ wide. In the observer's receiver masking elevation angle $\mathrm{H}_{\text {min }}$ was assumed to be $0^{\circ}$ (horizon), $5^{\circ}$ (the most frequently used value of $\mathrm{H}_{\text {min }}$ ), $10^{\circ}, 15^{\circ}, 20^{\circ}$ and $25^{\circ}$. The angle $25^{\circ}$ is representative for the positioning in restricted area where the visibility of satellites can be limited. This problem is very important in road transport (urban canyon) and in maritime transport in restricted area where the visibility of satellites is limited. 
Tab. 1. Global satellite navigation systems, parameters of spatial segment and time interval of constellation repeatability [www.beidou.gov.cn], [www.glonass-ianc.rsa.ru], [www.gps.gov], [European GNSS, 2016]

\begin{tabular}{|c|c|c|c|c|}
\hline System & $\begin{array}{c}\text { Orbit altitude } \\
{[\mathrm{km}]}\end{array}$ & $\begin{array}{c}\text { Orbit inclination } \\
{\left[{ }^{\circ}\right]}\end{array}$ & $\begin{array}{c}\text { Number of orbital } \\
\text { periods/time interval } \\
{[\mathrm{min}]}\end{array}$ & $\begin{array}{c}\text { Number of } \\
\text { MEO satellites }\end{array}$ \\
\hline BeiDou & 21,500 & 55 & $13 / 10,091.48$ & 27 \\
\hline Galileo & 23,222 & 56 & $17 / 14,360.75$ & 24 \\
\hline GLONASS & 19,100 & 64.8 & $17 / 11,488.44$ & 24 \\
\hline GPS & 20,183 & 55 & $2 / 1,435.94$ & 31 \\
\hline
\end{tabular}

Tab. 2. BeiDou system, geographical longitude of ascending node (An) and argument of latitude $(\mathrm{Al})$ of all $27 \mathrm{MEO}$ satellites

\begin{tabular}{|c|c|c|c|c|c|}
\hline \multicolumn{2}{|c|}{$\begin{array}{c}\text { Orbit I } \\
\text { An = 0 }\end{array}$} & \multicolumn{2}{c|}{$\begin{array}{c}\text { Orbit II } \\
\text { An }=\mathbf{1 2 0}^{\mathbf{O}}\end{array}$} & \multicolumn{2}{c|}{$\begin{array}{c}\text { Orbit III } \\
\text { An }=\mathbf{2 4 0}^{\mathbf{O}}\end{array}$} \\
\hline $\begin{array}{c}\text { No. } \\
\text { of sat }\end{array}$ & $\begin{array}{c}\text { Al } \\
{[\mathbf{d e g}]}\end{array}$ & $\begin{array}{c}\text { No. } \\
\text { of sat }\end{array}$ & $\begin{array}{c}\text { Al } \\
{[\mathbf{d e g}]}\end{array}$ & $\begin{array}{c}\text { No. } \\
\text { of sat }\end{array}$ & $\begin{array}{c}\text { Al } \\
{[\mathbf{d e g}]}\end{array}$ \\
\hline 1 & 0 & 10 & 13 & 19 & 26 \\
\hline 2 & 40 & 11 & 53 & 20 & 66 \\
\hline 3 & 80 & 12 & 93 & 21 & 106 \\
\hline 4 & 120 & 13 & 133 & 22 & 146 \\
\hline 5 & 160 & 14 & 173 & 23 & 186 \\
\hline 6 & 200 & 15 & 213 & 24 & 226 \\
\hline 7 & 240 & 16 & 253 & 25 & 266 \\
\hline 8 & 280 & 17 & 293 & 26 & 306 \\
\hline 9 & 320 & 18 & 333 & 27 & 346 \\
\hline
\end{tabular}

Tab. 3. Galileo system, GLONASS system, geographical longitude of ascending node (An) and argument of latitude (Al) of all 24 satellites

\begin{tabular}{|c|c|c|c|c|c|}
\hline \multicolumn{2}{|c|}{$\begin{array}{c}\text { Orbit I } \\
\text { An = 0 }\end{array}$} & \multicolumn{2}{c|}{$\begin{array}{c}\text { Orbit II } \\
\text { An }=\mathbf{1 2 0}^{\mathbf{O}}\end{array}$} & \multicolumn{2}{c|}{$\begin{array}{c}\text { Orbit III } \\
\text { An }=\mathbf{2 4 0}^{\mathbf{O}}\end{array}$} \\
\hline $\begin{array}{c}\text { No. } \\
\text { of sat }\end{array}$ & $\begin{array}{c}\text { Al } \\
{[\mathbf{d e g}]}\end{array}$ & $\begin{array}{c}\text { No. } \\
\text { of sat }\end{array}$ & $\begin{array}{c}\text { Al } \\
{[\mathbf{d e g}]}\end{array}$ & $\begin{array}{c}\text { No. } \\
\text { of sat }\end{array}$ & $\begin{array}{c}\text { Al } \\
{[\mathbf{d e g}]}\end{array}$ \\
\hline 1 & 0 & 9 & 15 & 17 & 30 \\
\hline 2 & 45 & 10 & 60 & 18 & 75 \\
\hline 3 & 90 & 11 & 105 & 19 & 120 \\
\hline 4 & 135 & 12 & 150 & 20 & 165 \\
\hline 5 & 180 & 13 & 195 & 21 & 210 \\
\hline 6 & 225 & 14 & 240 & 22 & 255 \\
\hline 7 & 270 & 15 & 285 & 23 & 300 \\
\hline 8 & 315 & 16 & 330 & 24 & 345 \\
\hline
\end{tabular}


Tab. 4. GPS system, geographical longitude of ascending node (An) and argument of latitude (Al) of all 31 satellites, PRN - Pseudo Random Noise (July 27, 2016)

\begin{tabular}{|c|c|c|c|c|c|c|c|}
\hline Orbit & PRN & An & Al & Orbit & PRN & An & Al \\
\hline \multirow{4}{*}{ A } & 7 & 353 & 290 & \multirow{5}{*}{ B } & 12 & 54 & 93 \\
\hline & 24 & 350 & 162 & & 16 & 55 & 315 \\
\hline & 30 & 355 & 266 & & 25 & 51 & 63 \\
\hline & 31 & 353 & 51 & & 26 & 51 & 343 \\
\hline \multirow{5}{*}{$\mathrm{C}$} & 8 & 111 & 232 & & 28 & 56 & 199 \\
\hline & 17 & 114 & 133 & \multirow{5}{*}{ D } & 1 & 172 & 152 \\
\hline & 19 & 117 & 110 & & 2 & 169 & 26 \\
\hline & 27 & 111 & 262 & & 6 & 171 & 61 \\
\hline & 29 & 114 & 5 & & 11 & 150 & 178 \\
\hline \multirow{6}{*}{$\mathrm{E}$} & 3 & 231 & 86 & & 21 & 170 & 284 \\
\hline & 5 & 231 & 316 & \multirow{6}{*}{$\mathrm{F}$} & 9 & 291 & 0 \\
\hline & 10 & 231 & 194 & & 13 & 298 & 251 \\
\hline & 18 & 229 & 226 & & 14 & 296 & 112 \\
\hline & 20 & 226 & 276 & & 15 & 298 & 228 \\
\hline & 22 & 229 & 108 & & 23 & 291 & 23 \\
\hline & 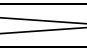 & & & & 32 & 291 & 132 \\
\hline
\end{tabular}

For each system, for each zone of latitude and for each masking elevation angle $\left(\mathrm{H}_{\min }\right)$ one thousand (1000) geographic-time coordinates of the observer were generated by random-number generator with uniform distribution:

- latitude interval 0-300 minutes $\left(5^{\circ}\right)$;

- longitude interval 0-21600 minutes $\left(360^{\circ}\right)$;

- time interval in minutes equal time of constellation repeatability (Table 1).

For each geographic-time coordinates: the number of visible satellites (1s), the satellite elevation $(\mathrm{H})$, the satellite azimuth $(\mathrm{Az})$, and GDOP (Geometric Dilution Of Precision) coefficient values were calculated. Elevation $\mathrm{H}$ was divided into 9 intervals, each $10^{\circ}$ wide, azimuth $(\mathrm{Az})$ was divided into 8 intervals, each $45^{\circ}$ and GDOP value (w) into 8 intervals: $w<2,2 \leq \mathrm{w}<3,3 \leq \mathrm{w}<4,4 \leq \mathrm{w}<5$, $5 \leq \mathrm{w}<6,6 \leq \mathrm{w}<8,8 \leq \mathrm{w}<20, \mathrm{w} \geq 20$.

\section{VISIBILITY OF SATELLITES}

The lowest $1 s_{\min }$ and the greatest $1 s_{\max }$ number of satellites of all four SNSs visible in open area by the observer at different latitudes for different $\mathrm{H}_{\text {min }}$ are showed in the Table 5. 
Tab. 5. Global Satellite Navigation Systems, the lowest and the greatest number of MEO satellites visible in open area above $\mathrm{H}_{\min }$ at different observer's latitudes

\begin{tabular}{|c|c|c|c|c|c|c|c|}
\hline \multirow{2}{*}{$\begin{array}{c}\text { Latitude } \\
{\left[{ }^{\circ}\right]}\end{array}$} & \multirow{2}{*}{ System } & \multicolumn{6}{|c|}{$H_{\text {min }}$} \\
\hline & & $0^{\circ}$ & $5^{\circ}$ & $10^{\circ}$ & $15^{\circ}$ & $20^{\circ}$ & $25^{\circ}$ \\
\hline \multirow{4}{*}{$60-65$} & BeiDou & $9-12$ & $8-11$ & $7-10$ & $5-9$ & $5-8$ & $4-7$ \\
\hline & Galileo & $9-11$ & $8-10$ & $7-9$ & $5-9$ & $4-7$ & $4-6$ \\
\hline & GLONASS & $9-11$ & $8-10$ & $7-9$ & $5-9$ & $4-7$ & $4-7$ \\
\hline & GPS & $9-16$ & $8-15$ & $7-13$ & $6-13$ & $5-11$ & $4-10$ \\
\hline \multirow{4}{*}{$65-70$} & BeiDou & $9-12$ & $8-12$ & $7-10$ & $6-10$ & $5-9$ & $4-7$ \\
\hline & Galileo & $9-11$ & $8-11$ & $7-9$ & $5-9$ & $5-8$ & $4-7$ \\
\hline & GLONASS & $9-11$ & $8-11$ & 7-9 & $6-9$ & $5-8$ & $4-7$ \\
\hline & GPS & $11-15$ & $10-14$ & $7-13$ & $7-13$ & $6-11$ & $4-10$ \\
\hline \multirow{4}{*}{$70-75$} & BeiDou & $9-12$ & $9-12$ & $8-11$ & $6-10$ & $5-8$ & $4-8$ \\
\hline & Galileo & $9-11$ & $8-11$ & $7-9$ & $5-9$ & $5-8$ & $4-7$ \\
\hline & GLONASS & $9-11$ & $8-11$ & $7-9$ & $6-9$ & $5-8$ & $5-8$ \\
\hline & GPS & $12-15$ & $11-14$ & $9-13$ & $7-13$ & $7-11$ & $4-10$ \\
\hline \multirow{4}{*}{$75-80$} & BeiDou & $9-12$ & $9-12$ & $8-11$ & $6-9$ & $5-9$ & $5-8$ \\
\hline & Galileo & $9-11$ & $8-10$ & $7-9$ & $6-9$ & $5-8$ & $5-7$ \\
\hline & GLONASS & $9-11$ & $8-10$ & $7-9$ & $6-9$ & $6-9$ & $5-8$ \\
\hline & GPS & $13-15$ & $11-14$ & $10-13$ & $9-12$ & $7-11$ & $6-10$ \\
\hline \multirow{4}{*}{$80-85$} & BeiDou & $9-12$ & $9-12$ & $8-10$ & $7-9$ & $6-9$ & $5-7$ \\
\hline & Galileo & $9-11$ & $8-11$ & $7-9$ & $7-9$ & $6-9$ & $5-7$ \\
\hline & GLONASS & $9-11$ & $8-11$ & $7-9$ & $7-9$ & $6-9$ & $5-7$ \\
\hline & GPS & $12-15$ & $11-14$ & $10-13$ & $9-12$ & $8-11$ & $7-10$ \\
\hline \multirow{4}{*}{$85-90$} & BeiDou & $10-12$ & $9-11$ & $9-10$ & $7-9$ & $6-8$ & $5-7$ \\
\hline & Galileo & $9-11$ & $9-10$ & $7-9$ & $7-9$ & $6-7$ & $5-7$ \\
\hline & GLONASS & $9-11$ & 9 & $7-9$ & $7-9$ & 7 & $5-7$ \\
\hline & GPS & $13-15$ & $11-14$ & $11-12$ & $10-11$ & $9-11$ & $7-9$ \\
\hline
\end{tabular}

We can resume that:

- the number ls of satellites decreases with $\mathrm{H}_{\min }$ in each zone and for all SNSs;

- if $\mathrm{H}_{\text {min }}=0^{\circ}$ the number $1 \mathrm{~s}_{\min }$ is the lowest (9) for each SNS in almost all zones, the $1 \mathrm{~s}_{\max }$ is the greatest (16) in zone $60-65^{\circ}$ for GPS system;

- if $\mathrm{H}_{\min }=0^{\circ}$ the numbers $1 \mathrm{~s}_{\min }$ and $1 \mathrm{~s}_{\max }$ are for Galileo and GLONASS systems in all 6 zones equal 9 and 11 respectively, if $\mathrm{H}_{\min }>0^{\circ}$ these numbers are for both systems almost the same in each zone;

- for BeiDou system the numbers $1 s_{\min }$ and $1 s_{\max }$ are for $\mathrm{H}_{\min } \leq 20^{\circ}$ at latitudes $60-85^{\circ}$ equal or greater than for Galileo and GLONASS systems;

- for GPS system the numbers $1 s_{\min }$ and $1 s_{\max }$ change between $4 \& 9$ and $9 \& 16$, respectively, it depends on not only angle $\mathrm{H}_{\min }$ but also latitude; at latitudes $75-90^{\circ}$ these numbers are in each zone greater than for all other systems;

- in zone $60-65^{\circ}$ the number $\mathrm{ls}_{\min }$ is for $\mathrm{H}_{\min } \leq 10^{\circ}$ the same for all SNSs, but $\mathrm{ls}_{\max }$ for GPS system is for all $\mathrm{H}_{\text {min }}$ greater than for other systems considerably; 
- for each SNS if $\mathrm{H}_{\min }=25^{\circ}$ the number ls can be equal 4 at latitudes $60-70^{\circ}$, and for all SNSs except for GLONASS in zone $70-75^{\circ}$ also; for two systems, Galileo and GLONASS, if $\mathrm{H}_{\min }=20^{\circ}$ the number ls can be equal 4 in zone $60-65^{\circ}$.

The 3D observer's position can be obtained only if the number of satellites ls used in position determination is at least 4. That's why the knowledge of information where and when ls is equal 4 is very important for all users. If one of these four satellites is for any raison out of service the user can determine $2 \mathrm{D}$ position only.

Tab. 6. BeiDou, Galileo, GLONASS and GPS systems, the greatest elevation $\mathrm{H}\left[{ }^{\circ}\right]$, $\mathrm{H}_{\max 4}$ and $\mathrm{H}_{\max 3}$, for which the number ls of satellites visible at different latitudes by the observer in open area above this angle is equal 4 or 3 , respectively

\begin{tabular}{|c|c|c|c|c|c|c|c|}
\hline \multirow{2}{*}{$\begin{array}{c}\text { Latitude } \\
{\left[{ }^{\circ}\right]}\end{array}$} & \multirow{2}{*}{ System } & \multicolumn{2}{|c|}{$\begin{array}{l}\text { Number ls } \\
\text { of satellites }\end{array}$} & \multirow{2}{*}{$\begin{array}{c}\text { Latitude } \\
{\left[{ }^{\circ}\right]}\end{array}$} & \multirow{2}{*}{ System } & \multicolumn{2}{|c|}{$\begin{array}{l}\text { Number ls } \\
\text { of satellites }\end{array}$} \\
\hline & & 4 & 3 & & & 4 & $\mathbf{3}$ \\
\hline \multirow{4}{*}{$60-65$} & BeiDou & 25 & 32 & \multirow{4}{*}{$75-80$} & BeiDou & 30 & 32 \\
\hline & Galileo & 26 & 33 & & Galileo & 29 & 31 \\
\hline & GLONASS & 28 & 37 & & GLONASS & 32 & 38 \\
\hline & GPS & 27 & 33 & & GPS & 29 & 32 \\
\hline \multirow{4}{*}{$65-70$} & BeiDou & 26 & 32 & \multirow{4}{*}{$80-85$} & BeiDou & 33 & 34 \\
\hline & Galileo & 25 & 33 & & Galileo & 32 & 35 \\
\hline & GLONASS & 31 & 35 & & GLONASS & 35 & 42 \\
\hline & GPS & 28 & 33 & & GPS & 33 & 34 \\
\hline \multirow{4}{*}{$70-75$} & BeiDou & 29 & 33 & \multirow{4}{*}{$85-90$} & BeiDou & 35 & 37 \\
\hline & Galileo & 29 & 30 & & Galileo & 34 & 38 \\
\hline & GLONASS & 30 & 33 & & GLONASS & 38 & 45 \\
\hline & GPS & 29 & 32 & & GPS & 37 & 39 \\
\hline
\end{tabular}

In this order the additional calculations were made for four SNSs for different $\mathrm{H}_{\min }$ in order to determine the greatest elevations $\mathrm{H}\left[^{\circ}\right], \mathrm{H}_{\max 4}$ and $\mathrm{H}_{\max 3}$, for which the number ls of satellites visible at different latitudes by the observer in open area above this angle is equal 4 or 3, respectively (Tab. 6). We can resume that:

- in each zone elevations $\mathrm{H}_{\max 4}$ and $\mathrm{H}_{\max 3}$ are the greatest for GLONASS system, $\mathrm{H}_{\max 3}$ at latitudes $75-90^{\circ}$ in particular;

- the elevation $\mathrm{H}_{\max 4}$ is the lowest (25) in zone $60-65^{\circ}$ for BeiDou system and in zone $65-70^{\circ}$ for Galileo system and the greatest (38) in zone $85-90^{\circ}$ for GLONASS system;

- the elevation $\mathrm{H}_{\max 3}$ is the lowest (30) in zone $70-75^{\circ}$ for Galileo system and the greatest (45) in zone $85-90^{\circ}$ for GLONASS system;

- for each SNSs the elevations $\mathrm{H}_{\max 4}$ and $\mathrm{H}_{\max 3}$ are in zone 85-90 greater than in zone $60-65^{\circ}$, considerably; 
- for each SNS and in each zone elevation $\mathrm{H}_{\max 3}$ is greater than $\mathrm{H}_{\max 4}$, this difference is the lowest (1) for Galileo system in zone $70-75^{\circ}$ and for BeiDou system and GPS system in zone $80-85^{\circ}$ and the greatest (9) for GLONASS system in zone $60-65^{\circ}$.

Tab. 7. Global Satellite Navigation Systems, percentage of MEO satellites visible in open area above angle $\mathrm{H}$ at different observer's latitudes $(\varphi), 1 \mathrm{~s}_{\mathrm{m}}$ - weighted mean number of satellites visible above horizon $\left(\mathrm{H}=0^{\circ}\right)$

\begin{tabular}{|c|c|c|c|c|c|c|c|c|c|c|c|}
\hline \multirow{2}{*}{$\begin{array}{c}\text { Latitude } \\
{\left[{ }^{\circ}\right]}\end{array}$} & \multirow{2}{*}{ System } & \multirow{2}{*}{$\mathbf{l} \mathbf{S m}$} & \multicolumn{9}{|c|}{ Angle $\mathrm{H}\left[^{\circ}\right]$} \\
\hline & & & $\mathbf{0}$ & 10 & 20 & 30 & 40 & 50 & 60 & 70 & 80 \\
\hline \multirow{4}{*}{$60-65$} & BDS & 10.8 & 100 & 79.7 & 56.6 & 40.6 & 28.6 & 18.4 & 10.6 & 4.1 & 0.4 \\
\hline & GAL & 9.8 & 100 & 81.2 & 58.1 & 41.3 & 29.5 & 19.9 & 10.8 & 4.4 & 0.6 \\
\hline & GLO & 9.6 & 100 & 84.4 & 66.5 & 52.0 & 33.4 & 22.8 & 14.1 & 7.7 & 2.6 \\
\hline & GPS & 12.9 & 100 & 85.1 & 57.7 & 41.9 & 28.7 & 19.9 & 11.5 & 4.5 & 0.4 \\
\hline \multirow{4}{*}{$65-70$} & BDS & 10.9 & 100 & 81.4 & 60.0 & 40.4 & 27.0 & 16.4 & 8.0 & 1.7 & 0 \\
\hline & GAL & 9.9 & 100 & 82.0 & 62.9 & 41.9 & 27.7 & 17.2 & 8.9 & 2.5 & 0 \\
\hline & GLO & 9.8 & 100 & 82.2 & 67.3 & 48.9 & 32.2 & 22.2 & 5.9 & 1.6 & 0.2 \\
\hline & GPS & 13.0 & 100 & 84.7 & 60.6 & 41.5 & 28.1 & 17.7 & 8.8 & 1.6 & 0 \\
\hline \multirow{4}{*}{$70-75$} & BDS & 10.9 & 100 & 82.7 & 63.4 & 40.7 & 25.3 & 14.2 & 4.8 & 0.1 & 0 \\
\hline & GAL & 10.0 & 100 & 83.0 & 64.4 & 43.4 & 28.4 & 12.3 & 9.5 & 0.3 & 0 \\
\hline & GLO & 9.8 & 100 & 84.7 & 68.7 & 53.5 & 34.4 & 20.2 & 11.7 & 4.7 & 0.3 \\
\hline & GPS & 12.8 & 100 & 84.2 & 65.6 & 41.8 & 27.1 & 15.1 & 4.4 & 0.1 & 0 \\
\hline \multirow{4}{*}{$75-80$} & BDS & 11.0 & 100 & 83.5 & 65.4 & 44.7 & 24.1 & 10.8 & 1.1 & 0 & 0 \\
\hline & GAL & 10.0 & 100 & 85.2 & 67.5 & 47.9 & 25.8 & 12.0 & 2.3 & 0 & 0 \\
\hline & GLO & 9.8 & 100 & 85.5 & 70.2 & 54.0 & 37.2 & 20.9 & 9.2 & 1.6 & 0 \\
\hline & GPS & 12.7 & 100 & 86.0 & 70.1 & 47.4 & 26.0 & 11.0 & 1.1 & 0 & 0 \\
\hline \multirow{4}{*}{$80-85$} & BDS & 11.1 & 100 & 82.7 & 65.1 & 47.6 & 23.5 & 5.8 & 0 & 0 & 0 \\
\hline & GAL & 10.0 & 100 & 81.5 & 65.8 & 50.6 & 28.1 & 8.7 & 0 & 0 & 0 \\
\hline & GLO & 9.9 & 100 & 82.7 & 69.8 & 57.5 & 40.2 & 19.9 & 6.5 & 0 & 0 \\
\hline & GPS & 12.8 & 100 & 84.3 & 69.4 & 52.4 & 24.8 & 4.5 & 0 & 0 & 0 \\
\hline \multirow{4}{*}{$85-90$} & BDS & 11.1 & 100 & 83.8 & 65.9 & 49.6 & 0.5 & 0 & 0 & 0 & 0 \\
\hline & GAL & 10.0 & 100 & 86.9 & 69.3 & 49.9 & 1.9 & 0 & 0 & 0 & 0 \\
\hline & GLO & 9.6 & 100 & 91.0 & 72.6 & 54.2 & 26.6 & 1.3 & 0 & 0 & 0 \\
\hline & GPS & 12.7 & 100 & 80.5 & 72.4 & 55.9 & 21.8 & 0.4 & 0 & 0 & 0 \\
\hline
\end{tabular}

The percentage of satellites visible (PSV) in open area by the observer above angle $\mathrm{H}$ at different latitudes and $1 \mathrm{~s}_{\mathrm{m}}$ - weighted mean number of satellites visible above horizon for all four global SNSs are presented in the Table 7. We can say that: - the number $1 \mathrm{~s}_{\mathrm{m}}$ is for Galileo system greater than for GLONASS system in each zone; indeed the number of satellites (24) and orbit (3) are for both systems the same but orbit altitude is in the case of Galileo $(23,222 \mathrm{~km})$ higher than for GLONASS $(19,100 \mathrm{~km})$;

- the PSV decreases with angle $H$ in all 6 zones, but this decrease is the most slowly in the case of GLONASS system, in zone $75-80^{\circ}$ the most significantly; 
- if angle $\mathrm{H}$ is equal $20^{\circ}$ the PSV for all SNSs decreases at latitudes $60-85^{\circ}$ to about 60 or more and in zone $85-90^{\circ}$ to about 70 ;

- if angle $\mathrm{H}$ is equal $50^{\circ}$ the PSV decreases at latitudes $60-80^{\circ}$ for all SNSs to a dozen or so except GLONASS system, near 20 , in zone $80-85^{\circ}$ to several and about 20, respectively;

- GLONASS system is the only system which satellites can be visible at latitudes $65-75^{\circ}$ above $80^{\circ}$, in zone $75-80^{\circ}$ above $70^{\circ}$, and in zone $80-85^{\circ}$ above $60^{\circ}$; in zone $85-90^{\circ}$ the satellites of two systems, GLONASS and Galileo, can be visible above $50^{\circ}$.

Tab. 8. Distribution (in per cent) of BeiDou MEO, Galileo, GLONASS and GPS satellites azimuths in open area for different masking elevation angles $\left(\mathrm{H}_{\min }\right)$ at different observer's latitudes $(\varphi)$ of hemisphere north, $1 \mathrm{~s}_{\mathrm{m}}$ — weighted mean number of satellites visible above $\mathrm{H}_{\min }$

\begin{tabular}{|c|c|c|c|c|c|c|c|c|c|c|c|}
\hline \multirow{2}{*}{$\begin{array}{c}\varphi \mathbf{N} \\
{\left[^{\circ}\right]}\end{array}$} & \multirow{2}{*}{$\begin{array}{l}\mathbf{H}_{\mathrm{mir}} \\
{\left[{ }^{\circ}\right]}\end{array}$} & \multirow{2}{*}{ System } & \multirow{2}{*}{$\mathbf{I S m}$} & \multicolumn{8}{|c|}{ Azimuth $\left[{ }^{\circ}\right]$} \\
\hline & & & & $0-45$ & 45-90 & 90-135 & $135-180$ & $180-225$ & $225-270$ & $270-315$ & $315-360$ \\
\hline \multirow{8}{*}{$65-70 \mid$} & \multirow{4}{*}{5} & BDS & 9.9 & 10.7 & 13.9 & 13.4 & 12.1 & 12.4 & 13.0 & 13.8 & 10.7 \\
\hline & & GAL & 9.0 & 11.1 & 14.0 & 12.5 & 12.2 & 12.4 & 12.8 & 13.9 & 11.1 \\
\hline & & GLO & 8.9 & 12.6 & 15.0 & 11.7 & 10.3 & 10.6 & 12.0 & 14.9 & 12.9 \\
\hline & & GPS & 12.0 & 11.3 & 14.0 & 13.0 & 11.6 & 11.6 & 13.0 & 14.1 & 11.4 \\
\hline & \multirow{4}{*}{25} & BDS & 5.3 & 1.8 & 15.6 & 17.5 & 15.1 & 15.5 & 17.1 & 15.5 & 1.9 \\
\hline & & GAL & 5.0 & 3.1 & 15.9 & 15.7 & 15.1 & 15.1 & 16.0 & 15.9 & 3.2 \\
\hline & & GLO & 5.7 & 10.3 & 17.2 & 13.0 & 9.6 & 9.9 & 13.1 & 16.9 & 10.0 \\
\hline & & GPS & 6.5 & 1.4 & 16.8 & 17.1 & 14.7 & 15.2 & 17.1 & 16.3 & 1.4 \\
\hline \multirow{8}{*}{$75-80$} & \multirow{4}{*}{5} & BDS & 10.1 & 11.6 & 13.1 & 12.8 & 12.4 & 12.5 & 12.8 & 13.1 & 11.7 \\
\hline & & GAL & 9.1 & 12.0 & 12.9 & 12.5 & 12.5 & 12.8 & 12.6 & 12.7 & 12.0 \\
\hline & & GLO & 9.1 & 12.0 & 13.7 & 12.2 & 11.7 & 12.1 & 12.0 & 14.0 & 12.3 \\
\hline & & GPS & 12.1 & 12.2 & 12.5 & 13.1 & 12.3 & 11.7 & 13.2 & 12.5 & 12.5 \\
\hline & \multirow{4}{*}{25} & BDS & \begin{tabular}{|l|}
6.1 \\
\end{tabular} & 9.5 & 13.0 & 13.8 & 13.8 & 13.6 & 14.2 & 12.7 & 9.4 \\
\hline & & GAL & 5.8 & 10.3 & 12.6 & 13.8 & 13.3 & 13.5 & 14.0 & 12.5 & 10.0 \\
\hline & & GLO & 6.2 & 12.8 & 12.9 & 12.6 & 11.7 & 12.0 & 12.0 & 13.4 & 12.6 \\
\hline & & GPS & 7.7 & 8.7 & 13.6 & 14.6 & 12.9 & 12.3 & 14.9 & 13.6 & 9.4 \\
\hline \multirow{8}{*}{ 85-90 } & \multirow{4}{*}{5} & BDS & 10.2 & 11.9 & 12.9 & 12.1 & 12.6 & 12.6 & 12.2 & 12.8 & 12.9 \\
\hline & & GAL & 9.2 & 12.6 & 12.4 & 12.4 & 12.4 & 12.5 & 12.5 & 12.6 & 12.6 \\
\hline & & GLO & 9.0 & 12.8 & 13.2 & 12.0 & 11.6 & 12.3 & 11.7 & 13.1 & 13.3 \\
\hline & & GPS & 12.5 & 12.1 & 12.6 & 12.4 & 12.8 & 12.1 & 13.2 & 12.5 & 12.3 \\
\hline & \multirow{4}{*}{25} & BDS & \begin{tabular}{|l|}
6.3 \\
\end{tabular} & 12.6 & 12.4 & 13.2 & 13.0 & 12.9 & 12.3 & 12.0 & 12.6 \\
\hline & & GAL & 6.0 & 12.6 & 11.7 & 13.1 & 12.8 & 12.6 & 12.9 & 12.0 & 12.3 \\
\hline & & GLO & 6.6 & 11.2 & 13.5 & 12.9 & 12.4 & 13.0 & 12.4 & 13.1 & 11.5 \\
\hline & & GPS & 8.5 & 12.2 & 12.3 & 12.1 & 13.1 & 12.6 & 12,9 & 12.2 & 12.6 \\
\hline
\end{tabular}


Distribution (in per cent) of four SNSs satellites azimuths (DSA) in open area for $\mathrm{H}_{\min }=5^{\circ}$ and $25^{\circ}$ in three selected zones of latitude of hemisphere north and weighted mean number of satellites visible above $H_{\min }\left(1 s_{m}\right)$ are showed in the Table 8 . We can say that:

- if $\mathrm{H}_{\min }=5^{\circ}$ the number $1 \mathrm{~s}_{\mathrm{m}}$ is the lowest for GLONASS system in each zone and the greatest for GPS system in each zone;

- if $\mathrm{H}_{\min }=25^{\circ}$ the number $\mathrm{l}_{\mathrm{m}}$ is the lowest for Galileo system in each zone and the greatest for GPS in each zone; for GLONASS system even though its number of satellites (24) is the lowest, the number $1 s_{m}$ is greater than for BeiDou system (27 satellites) also;

- if $\mathrm{H}_{\min }=5^{\circ}$ the DSA is for all SNSs almost even in 8 intervals in all zones, if $\mathrm{H}_{\min }=25^{\circ}$ in zone $85-90^{\circ}$ only;

- if $\mathrm{H}_{\min }=25^{\circ}$ in zone $65-70^{\circ}$ the percentage of satellites with azimuths from intervals $315-360^{\circ}$ and $000-045^{\circ}$ is for BeiDou, Galileo and GPS systems less than in all other intervals considerably, in zone $75-80^{\circ}$ this percentage is for BeiDou and GPS systems for the same interval less than in all other intervals.

\section{GEOMETRY OF SATELLITES}

The distribution (in per cent) of GDOP coefficient values for $\mathrm{H}_{\min }=5^{\circ}$ and $25^{\circ}$ in four selected zones of latitude for all SNSs is showed in the Table 9. We can found that:

- GDOP value increases with latitude and $\mathrm{H}_{\min }$ for all SNSs;

- for $\mathrm{H}_{\min }=5^{\circ} \mathrm{GDOP}$ value can be less than 3 in zone $60-65^{\circ}$ for all SNSs and in zone $70-75^{\circ}$ for BeiDou system only;

- for $\mathrm{H}_{\text {min }}=5^{\circ}$ GDOP value is in zone $60-65^{\circ}$ less than 4 for Galileo and GLONASS systems and less than 5 for BeiDou and GPS systems and in zone $70-75^{\circ}$ less than 5 for all SNSs;

- for $\mathrm{H}_{\min }=25^{\circ}$ for all SNSs GDOP value in zone $60-65^{\circ}$ can be less than 4 and greater than 20 , at latitude $80-90^{\circ}$ this coefficient is between 6 and 20 . 
Tab. 9. BeiDou, Galileo, GLONASS and GPS systems, distribution (in per cent) of GDOP coefficient values for different masking elevation angles $\mathrm{H}_{\min }$ at different observer's latitudes $(\varphi)$

\begin{tabular}{|c|c|c|c|c|c|c|c|c|c|}
\hline \multirow{2}{*}{\begin{tabular}{|c} 
Latitude \\
{$\left[{ }^{\circ}\right]$}
\end{tabular}} & \multirow{2}{*}{$\begin{array}{c}\mathbf{H}_{\min } \\
{\left[{ }^{\circ}\right]}\end{array}$} & \multirow{2}{*}{ System } & \multicolumn{7}{|c|}{ GDOP coefficient $w$} \\
\hline & & & $2 \leq w<3$ & $3 \leq w<4$ & $4 \leq w<5$ & $5 \leq w<6$ & $6 \leq w<8$ & $8 \leq w<20$ & $w \geq 20$ \\
\hline \multirow{8}{*}{$60-65$} & \multirow{4}{*}{5} & BeiDou & 45.9 & 53.9 & 0.2 & - & - & - & - \\
\hline & & Galileo & 39.9 & 60.1 & - & - & - & - & - \\
\hline & & GLONASS & 33.8 & 66.2 & - & - & - & - & - \\
\hline & & GPS & 47.4 & 52.1 & 0.5 & - & - & - & - \\
\hline & \multirow{4}{*}{25} & BeiDou & - & 2.7 & 35.8 & 51.4 & 1.0 & 6.3 & 2.8 \\
\hline & & Galileo & - & 5.0 & 51.7 & 7.2 & 10.0 & 19.2 & 6.9 \\
\hline & & GLONASS & - & 12.5 & 38.5 & 16.1 & 0.8 & 28.9 & 3.2 \\
\hline & & GPS & - & 12.0 & 19.3 & 6.8 & 38.1 & 20.0 & 3.8 \\
\hline \multirow{8}{*}{$70-75$} & \multirow{4}{*}{5} & BeiDou & 0.1 & 71.6 & 28.3 & - & - & - & - \\
\hline & & Galileo & - & 44.7 & 55.3 & - & - & - & - \\
\hline & & GLONASS & - & 55.4 & 44.6 & - & - & - & - \\
\hline & & GPS & - & 66.6 & 33.2 & - & - & - & - \\
\hline & \multirow{4}{*}{25} & BeiDou & - & - & 16.7 & 36,5 & 16.2 & 23.0 & 7.6 \\
\hline & & Galileo & - & - & 20.4 & 22.0 & 16.9 & 40.8 & - \\
\hline & & GLONASS & - & - & 23.2 & 26.9 & 23.9 & 26.0 & - \\
\hline & & GPS & - & - & 16.2 & 28.1 & 30.8 & 24.5 & 0.4 \\
\hline \multirow{8}{*}{$80-85$} & \multirow{4}{*}{5} & BeiDou & - & - & 1.9 & 29.8 & 51.4 & 16.9 & - \\
\hline & & Galileo & - & - & 0.5 & 22.7 & 55.6 & 21.2 & - \\
\hline & & GLONASS & - & - & 0.5 & 20.6 & 52.8 & 26.1 & - \\
\hline & & GPS & - & - & 3.6 & 28.7 & 49.7 & 18.0 & - \\
\hline & \multirow{4}{*}{25} & BeiDou & - & - & - & - & 21.7 & 78.3 & - \\
\hline & & Galileo & - & - & - & - & 13.7 & 86.3 & - \\
\hline & & GLONASS & - & - & - & - & 14.6 & 85.4 & - \\
\hline & & GPS & - & - & - & - & 11.0 & 89.0 & - \\
\hline \multirow{8}{*}{$85-90$} & \multirow{4}{*}{5} & BeiDou & - & - & - & - & 57.0 & 43.0 & - \\
\hline & & Galileo & - & - & - & - & 55.8 & 44.2 & - \\
\hline & & GLONASS & - & - & - & - & 52.7 & 47.3 & - \\
\hline & & GPS & - & - & - & 0.2 & 58.9 & 40.9 & - \\
\hline & \multirow{4}{*}{25} & BeiDou & - & - & - & - & 43.1 & 56.9 & - \\
\hline & & Galileo & - & - & - & - & 44.8 & 55.2 & - \\
\hline & & GLONASS & - & - & - & - & 38.1 & 61.9 & - \\
\hline & & GPS & - & - & - & - & 45.2 & 54.8 & - \\
\hline
\end{tabular}

Additionally the distribution (in per cent) of GDOP coefficient values for all four SNSs at observer's latitude $75-80^{\circ}$ for $\mathrm{H}_{\min }=5^{\circ}$, if the number of visible satellites ls is known is presented in the Table 10. We can say that:

- for Beidou system GDOP is equal or greater than 4 and less than 8 if $1 \mathrm{~s}=9$, equal or greater than 3 and less than 6 if $1 \mathrm{~s}=10$ or 11 , equal or greater than 3 and less than 5 if $1 \mathrm{~s}=12$; 
- for Galileo system GDOP is equal or greater than 4 and less than 6 if ls $=8$, equal or greater than 3 and less than 8 if $1 s=9$, equal or greater than 3 and less than 6 if $1 \mathrm{~s}=10$;

- for GLONASS system GDOP is equal or greater than 4 and less than 8 if $1 \mathrm{~s}=8$, equal or greater than 3 and less than 6 if $1 s=9$ or 10 ;

- for GPS system GDOP is equal or greater than 5 and less than 8 if ls $=11$, equal or greater than 3 and less than 8 if $1 \mathrm{~s}=12$ or 13 , equal or greater than 3 and less than 5 if $1 \mathrm{~s}=14$;

- there is not a direct relation between the number ls of satellites visible above $\mathrm{H}_{\min }=5^{\circ}$ and GDOP coefficient value but in the case of all four SNSs we can realize 'when ls is greater, GDOP can be less' and vice versa 'when ls is less, GDOP can be greater'; the calculations made for all other zones confirm this relation also.

Tab. 10. BeiDou, Galileo, GLONASS and GPS system, distribution (in per cent) of GDOP coefficient values in zone $75-80^{\circ}, \mathrm{H}_{\min }=5^{\circ}$, if the number of visible satellites $1_{\mathrm{S}}$ is known

\begin{tabular}{|c|c|c|c|c|c|c|}
\hline \multirow{2}{*}{ Is } & \multirow{2}{*}{ System } & \multirow{2}{*}{} & \multicolumn{4}{|c|}{ GDOP coefficient $\mathbf{w}$} \\
\cline { 3 - 7 } & & & $\mathbf{3} \leq \mathbf{w}<\mathbf{4}$ & $\mathbf{4} \leq \mathbf{w}<\mathbf{5}$ & $\mathbf{5} \leq \mathbf{w}<\mathbf{6}$ & $\mathbf{6} \leq \mathbf{w}<\mathbf{8}$ \\
\hline \multirow{3}{*}{8} & Galileo & 10.7 & - & 6.7 & 4.0 & - \\
\cline { 2 - 7 } & GLONASS & 8.9 & - & 3.1 & 5.6 & 0.2 \\
\hline \multirow{4}{*}{9} & BeiDou & 28.7 & - & 8.7 & 18.9 & 1.1 \\
\cline { 2 - 7 } & Galileo & 70.2 & 0.9 & 43.1 & 26.1 & 0.1 \\
\cline { 2 - 7 } & GLONASS & 75.5 & 2.0 & 49.8 & 23.7 & - \\
\hline \multirow{3}{*}{10} & BeiDou & 40.8 & 0.3 & 32.8 & 7.7 & - \\
\cline { 2 - 7 } & Galileo & 19.1 & 5.3 & 13.1 & 0.7 & - \\
\cline { 2 - 7 } & GLONASS & 15.6 & 4.4 & 10.7 & 0.5 & - \\
\hline \multirow{2}{*}{11} & BeiDou & 25.5 & 5.8 & 19.4 & 0.3 & - \\
\cline { 2 - 7 } & GPS & 1.8 & - & - & 0.9 & 0.9 \\
\hline \multirow{2}{*}{12} & BeiDou & 5.0 & 0.6 & 4.4 & - & - \\
\cline { 2 - 7 } & GPS & 33.9 & 1.1 & 20.2 & 11.4 & 1.2 \\
\hline 13 & GPS & 56.1 & 6.4 & 37.3 & 12.3 & 0.1 \\
\hline 14 & GPS & 8.2 & 4.5 & 3.7 & - & - \\
\hline \multirow{3}{*}{ Total } & BeiDou & 100 & 6.7 & 65.3 & 26.9 & 1.1 \\
\cline { 2 - 7 } & Galileo & 100 & 6.2 & 62.9 & 30.8 & 0.1 \\
\cline { 2 - 7 } & GLONASS & 100 & 6.4 & 63.6 & 29.8 & 0.2 \\
\cline { 2 - 7 } & GPS & 100 & 12.0 & 61.2 & 24.6 & 2.2 \\
\hline
\end{tabular}




\section{CONCLUSIONS}

1. Despite the different number of satellites (24 - Galileo and GLONASS, 27 BeiDou) the lowest and the greatest numbers of satellites visible by the observer are in almost all zones and for almost values of $\mathrm{H}_{\min }$ the same for all SNSs.

2. In the case of all global SNSs we can realize that at latitudes higher than $65^{\circ}$ 'when latitude is greater angle $\mathrm{H}$ above which the satellite can be visible by the user is less'.

3. The greatest elevation for which the number of satellites visible by the observer is equal 3 or 4 is at latitudes $60-90^{\circ}$ in the case of GLONASS system even though its constellation consists of the lowest number of satellites, 24 only. It means that for this system the possibility of the position's determination, $2 \mathrm{D}$ and $3 \mathrm{D}$, is the greatest.

4. Because of orbit altitude and orbit inclination and geometrical figure of the Earth GLONASS system is the only SNS which satellites can be visible above $60^{\circ}, 70^{\circ}$ or $80^{\circ}$ by the user at latitudes $65^{\circ}$ or higher. Therefore this system is useful in restricted area where the visibility of satellites is limited.

5. Distribution of GDOP coefficient value is independently of $\mathrm{H}_{\min }$ at latitudes $60-90^{\circ}$ almost the same for all four SNSs, despite of that the number of GPS satellites (31) is greater than in the case of Galileo and GLONASS (24), considerably.

6. Four global satellite navigation systems, different orbit parameters, different satellite constellations, each system can be used at high latitudes but the geometry and visibility of satellites is the best in the case of GLONASS system.

\section{REFERENCES}

[1] European GNSS Service Centre, Constellation Information, 2016.

[2] Januszewski J., The Analysis of the possibility of the simultaneous use of two and more satellite navigation systems in different modes of transport, Transport Systems Telematics conference, Katowice - Ustroń, 2016.

[3] Munich Satellite Navigation Summit, Munich 2016.

[4] www.beidou.gov.cn [access 29.08.2016].

[5] www.globalnews.ca [access 30.08.2016]. 
[6] www.glonass-ianc.rsa.ru [access 30.08.2016].

[7] www.gps.gov [access 27.07.2016].

[8] www.gpsworld.com [access 29.08.2016].

[9] www.gsc.europa.eu [access 31.08.2016].

[10] www.insidegnss.com [access 31.08.2016].

Received September 2016

Reviewed December 2016

\section{JACEK JANUSZEWSKI}

Gdynia Maritime University

Jana Pawła II 3 Str., 81-345 Gdynia, Poland

e-mail: jacekjot@am.gdynia.pl

\section{STRESZCZENIE}

Od kilku lat znaczenie nawigacji na dużych szerokościach geograficznych $\left(60^{\circ}\right.$ i wyższych) wzrasta nieprzerwanie, np. przejście północne łączące Atlantyk i Ocean Spokojny. W tych rejonach współrzędne użytkownika mogą zostać określone głównie za pomocą globalnych nawigacyjnych systemów satelitarnych (NSS). Obecnie (sierpień 2016) w pełni operacyjne są dwa systemy — amerykański GPS i rosyjski GLONASS, dwa kolejne są w budowie - Galileo w Europie i BeiDou w Chinach. Z uwagi na to, że błąd pozycji użytkownika określonej za pomocą tych systemów zależy również od współczynnika geometrycznego DOP, bardzo istotna jest znajomość liczby satelitów widocznych przez użytkownika powyżej przyjętej wysokości $\mathrm{H}_{\min }$ oraz rozkładu współczynnika DOP, w szczególności GDOP. W artykule omówiono najmniejszą i największą liczbę satelitów widocznych powyżej danej $\mathrm{H}_{\min }$, procent satelitów widocznych powyżej danej $\mathrm{H}$, procentowy rozkład azymutów satelitów oraz współczynnika GDOP na różnych szerokościach dla wszystkich czterech globalnych NSS. Obliczenia zostały zrealizowane przy założeniu, że system BeiDou liczy 27 satelitów, system Galileo 24 satelity, GLONASS 24 satelity, GPS zaś 31 satelitów. 